\title{
Pandemic Elections and the Covid-Safe Effect: Incumbents Re-elected in Six Covid-19 Safe Havens
}

\author{
John Paull \\ University of Tasmania, Hobart, Tasmania, Australia \\ j.paull@utas.edu.au, john.paull@mail.com
}

\begin{abstract}
The Antipodes have been amongst the safest places on the planet during the Covid-19 pandemic. The governments of Australia and New Zealand (national, state, and territory governments) have acted promptly, decisively, and cohesively in closing borders, quarantining incoming returnees, instigating rigorous contact tracing and extensive testing, social distancing, hand washing, masks, and occasional lockdowns. Antipodean governments and populations have long experience of awareness and compliance with biosecurity issues. Isolation and distance have long served to keep Australia and New Zealand free of many pests and diseases. Each Antipodean election held during the Covid-19 pandemic has returned the incumbent. During the first 14 months of the pandemic, six out of six incumbent governments facing elections during the Covid pandemic have been returned. Five returned incumbents were center-left while the sixth was centerright. Four of the elections have rewarded the incumbent government with an increased majority, the Northern Territory election returned a reduced majority, and the Tasmanian election returned the status quo with the narrowest of majorities maintained. The New Zealand election returned the Labor government to power in their own right and released them from the coalition. The Western Australian election saw Labor returned with a landslide result with an unprecedented, win of 53 out of 59 seats ( $90 \%$ of seats). The object of the present paper is to report the outcomes of the six antipodean elections conducted during the Covid-19 pandemic (to date) and to reflect on the Covid-safe effect on them if any.
\end{abstract}

Keywords: Covid-19, Coronavirus, SARS-CoV-2, Covid-safe, politics, Australian Capital Territory, Northern Territory, Queensland, Tasmania, Western Australia.

\section{Introduction}

Australia and New Zealand have been the safest, or among the safest, places in the world during the Covid-19 pandemic. The pandemic was declared by the World Health Organization on 11 March 2020 (Ghebreyesus, 2020). As of the end of March 2021, Australia has accounted for a total of 909 Covid-19 deaths through the course of the pandemic, with no Covid deaths in 2021 (to the end of March 2021) (DoH, 2021). New Zealand has accounted for 26 Covid deaths, with a single death in 2021 (Worldometer, 2021a). These statistics are in stark contrast to a world total exceeding 2.7 million Covid deaths (Worldometer, 2021b). In the fourteen months since the pandemic was declared, there have been six elections in the Antipodes. The object of the present paper is to report the outcomes of those elections and reflect on the effect of Covid-19 on them if any. In an election, the advantage is to the incumbent; this is a result widely reported, in Australia, the USA, Ireland, Spain and elsewhere (Aiton \& Lane, 2000; Ramos \& Sanz, 2019; Redmond \& Regan, 2015). The incumbency advantage reportedly delivers a candidate an $18 \%$ advantage of winning a seat in Ireland in "the next election" (Redmond \& Regan, 2015, p.244). Voting is compulsory in Australia (Farrell \& McAllister, 2006; Fowler, 2013). Citizens who do not vote are at risk of being fined. The outcome of this policy is high participation rates.

The participation rate was $92 \%$ and $91 \%$ respectively in the last two federal elections in Australia (AEC, 2019). Voting is not compulsory in New Zealand, nevertheless, voter turnout is high, from a low, over the past three decades, of $74 \%$ in 2011 to a high of $94 \%$ in 1984, with a turnout of $82 \%$ in 2020 (Electoral Commission, 2020). Australia and New Zealand were two of the earliest countries to grant women the right to vote (in 1902 and 1893 respectively) (Adams, 2014; Aiton \& Lane, 2000). Despite the 'incumbency advantage' electorates can vote incumbents out, even in times of crisis. During World War I, the Australian Labor Party lost the 1916 election to the Nationalist Party of Billy Hughes. The incumbent Nationalist government was returned during the Spanish Flu pandemic in the 1919 election (Aiton \& Lane, 2000; Barber, 2017). During World War II, the incumbent United Australia Party under Prime Minister Robert Menzies (1939-1941) lost favor with voters and the Australian Labor Party took government under Prime Minister John Curtin in October 1941 (Aiton \& Lane, 2000; Farrell \& McAllister, 2006; JCPML, 2006). Election results are aggregations of myriad, diverse and multifactorial voter sentiments. In the 2013 Federal election in Australia, $46 \%$ of 
voters reported that they "Always voted for the same party", 33\% stated that they "Took 'a good deal' of interest in the election campaign overall", and 68\% "Cared 'a good deal' which party won" (Bean \& McAllister, 2015).

In the 2019 Federal election in Australia, 66\% of voters voted based on policy issues, while $7 \%$ voted based on party leader (Cameron \& McAllister, 2019). Voter choices in Australia are about policies, parties and leaders. Sometimes one or several issues dominate political campaigns and debates, but Australian elections are not single-issue elections. The pandemic election results reported in the present paper are no exception; the social, economic and health context of these elections held during the Covid-19 pandemic is expected to play into the election results, but not be the sole determinant.

\section{Methods}

There have been six elections in the Antipodes during the first 14 months of the Covid pandemic (in the period March 2020 through May 2021). Elections (national, state and territory) are managed by the respective electoral commissions of the six jurisdictions. The results data of the various elections were sourced from the respective electoral commissions:

- Australian Capital Territory Electoral Commission (www.elections.act.gov.au);

- Electoral Commission of New Zealand (www.electionresults.govt.nz);

- Electoral Commission of Queensland (www.ecq.qld.gov.au);

- $\quad$ Northern Territory Electoral Commission (ntec.nt.gov.au);

- Tasmanian Electoral Commission (www.tec.tas.gov.au); and the

- Western Australian Electoral Commission (www.elections.wa.gov.au).

Parliaments in the Antipodes are either unicameral (with a single chamber of parliament) or bicameral (with a lower house of representatives responsible for initiating legislation and wielding the power of government, along with an upper house of review). Of the six electoral jurisdictions reported in the present paper, four are unicameral (viz. Australian Capital Territory; New Zealand; Northern Territory; and Queensland). Where there is a bicameral parliament (viz. Tasmania and Western Australia), the lower house results determine who governs the state, and these are the results that are reported here.

\section{Results}

During the first fourteen months of the Covid-19 pandemic, the Antipodes has been a safe haven (Table 1) and this has enabled a more 'normal' social and business environment for the populations compared to other jurisdictions where the pandemic has reaped more lives lost and greater economic costs.

Table 1: Total Covid-19 Cases and Deaths (as at 31 March 2021) (data sources: DoH, 2021; Worldometer, 2021a, 2021b)

\begin{tabular}{lll}
\hline Jurisdiction & Covid Cases & Covid Deaths \\
\hline Australian Capital Territory (ACT) & 123 & 3 \\
New South Wales (NSW) & 5,288 & 54 \\
Northern Territory (NT) & 108 & 0 \\
Queensland (QLD) & 1,466 & 6 \\
South Australia (SA) & 655 & 4 \\
Tasmania (TAS) & 234 & 13 \\
Victoria & 20,484 & 820 \\
Western Australia (WA) & 938 & 9 \\
\hline
\end{tabular}


AUSTRALIA

NEW ZEALAND

WORLD
29,296

2,495

$128,773,247$
909

26

$2,814,771$

The results of the six Covid-19 pandemic elections are presented in Table 2. Incumbent governments were returned in all six cases. Five of the elected governments are center-left governments: 'Labor' in Australia (Australian Labor Party, ALP) and 'Labor' in New Zealand (New Zealand Labor Party, NZLP); note the two homophonic spelling variations, 'Labor' in Australia, and 'Labor' in New Zealand). The election in Tasmania returned the incumbent center-right Liberal Party government.

Table 2: Election Outcomes for the 6 Antipodean Pandemic Elections

\begin{tabular}{|c|c|c|c|c|c|c|}
\hline Jurisdiction & Election Date & Seats Before & $\begin{array}{l}\text { Government } \\
\text { Before Election }\end{array}$ & $\begin{array}{l}\text { Seats } \\
\text { After }\end{array}$ & $\begin{array}{l}\text { Government } \\
\text { After } \\
\text { Election }\end{array}$ & $\begin{array}{l}\text { Seats } \\
\text { Total }\end{array}$ \\
\hline $\begin{array}{l}\text { Northern } \\
\text { Territory (NT) }\end{array}$ & $22-8-2020$ & 16 & Labor & 14 & Labor & 25 \\
\hline $\begin{array}{l}\text { Australian Capital } \\
\text { Territory (ACT) }\end{array}$ & $\begin{array}{l}28-9-2020 \text { to } 17- \\
10-2020\end{array}$ & $14(12+2)$ & Labor/Green & $\begin{array}{l}16 \\
(10+6)\end{array}$ & Labor/Green & 25 \\
\hline New Zealand (NZ) & $17-10-2020$ & $63(46+9+8)$ & $\begin{array}{l}\text { Labour/NZ } \\
\text { First/Green }\end{array}$ & 65 & Labour & 120 \\
\hline Queensland (QLD) & $31-10-2020$ & 48 & Labor & 52 & Labor & 93 \\
\hline $\begin{array}{l}\text { Western Australia } \\
\text { (WA) }\end{array}$ & $13-3-2021$ & 41 & Labor & 53 & Labor & 59 \\
\hline Tasmania (TAS) & $1-5-2021$ & 13 & Liberal & 13 & Liberal & 25 \\
\hline
\end{tabular}

The Covid pandemic election results have been progressively more favorable to the incumbent government as the pandemic has progressed (Table 2) with the exception of Tasmania where the incumbent government 'scraped in' with the narrowest of margins. The first Antipodean Covid-19 election saw the incumbent Labor (ALP) government (with Chief Minister of the Northern Territory Michael Gunner) returned for a second term, albeit with a reduced majority. Each subsequent Covid election has seen the incumbent government returned with an increased number of seats, with the exception of Tasmania where the status quo prevailed. The second Covid pandemic election saw the Labor/Green coalition returned in the Australian Capital Territory (ACT) (Chief Minister of the ACT Andrew Barr) with an increased majority (Table 2). It was the sixth consecutive term for Labor, although in this election Labor seats were reduced from 12 to 10, while Green seats increased from two to six. The result was a net increase of seats for the Labor/Green coalition, up from 14 to 16 seats. The third Covid pandemic election saw NZ Prime Minister Jacinda Ardern lead Labor into a majority government. It was the first majority government for NZ Labor since 1946.

Prior to the 2020 pandemic election, Labor (with 46 seats) had been in coalition with the New Zealand First party ( 9 seats) and the Greens (8 seats). In the 2020 pandemic election, Labor won 65 seats in their own right (an increase of 19), New Zealand First slipped to zero seats, and the Greens won 10 seats (an increase of 2). The fourth Covid pandemic election was in Queensland. Labor was returned for a third term with an increased majority. For Queensland Premier Annastacia Palaszczuk, it was a historic win with Labor achieving an increased majority in three consecutive elections, and Palaszczuk becoming the first woman party leader in Australia to win three terms of government. The fifth Covid pandemic election, the WA election, took place a year after the WHO declared Covid-19 as a pandemic. The WA election result was an unprecedented win. The Labor government of Premier Mark McGowan won 53 seats (90\%) out of a total of 59 seats for the WA House of Representatives, with just two seats retained by the Liberal Party (down from 
13) and four seats retained by the National Party (down from 5) (Figs. 1\&3). Labor attracted 60\% of the popular vote, the Liberals $21 \%$, and the Nationals $4 \%$ (Fig.2).

Figure 1: Percentage of Seats Won in the WA 2021 Election - A Big Win for the Incumbent Labor Government

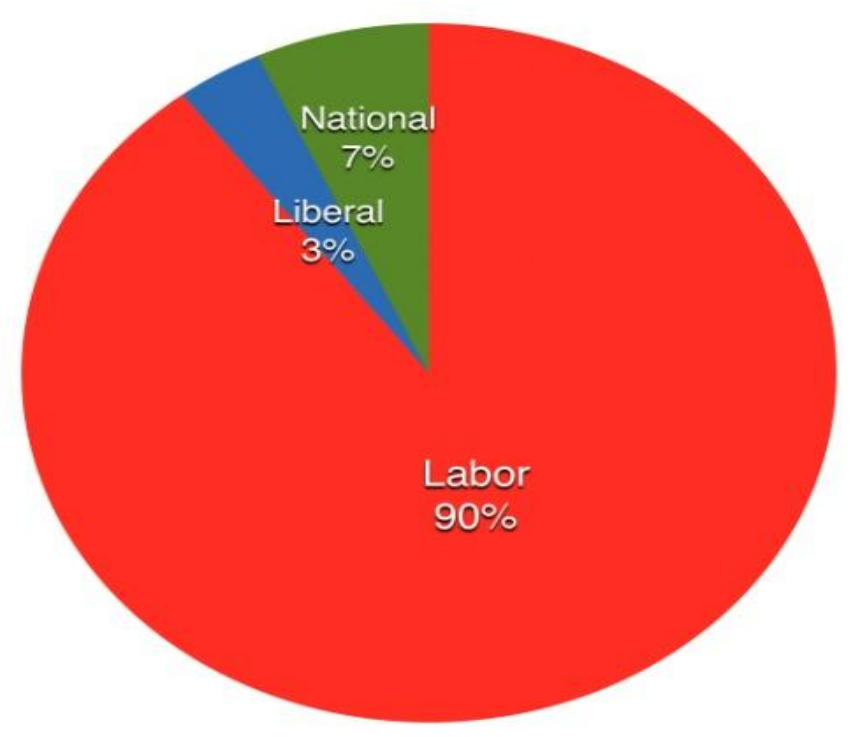

Figure 2: Percentage of the Primary Vote Won by Parties ( $=20)$ in the WA 2021 Election

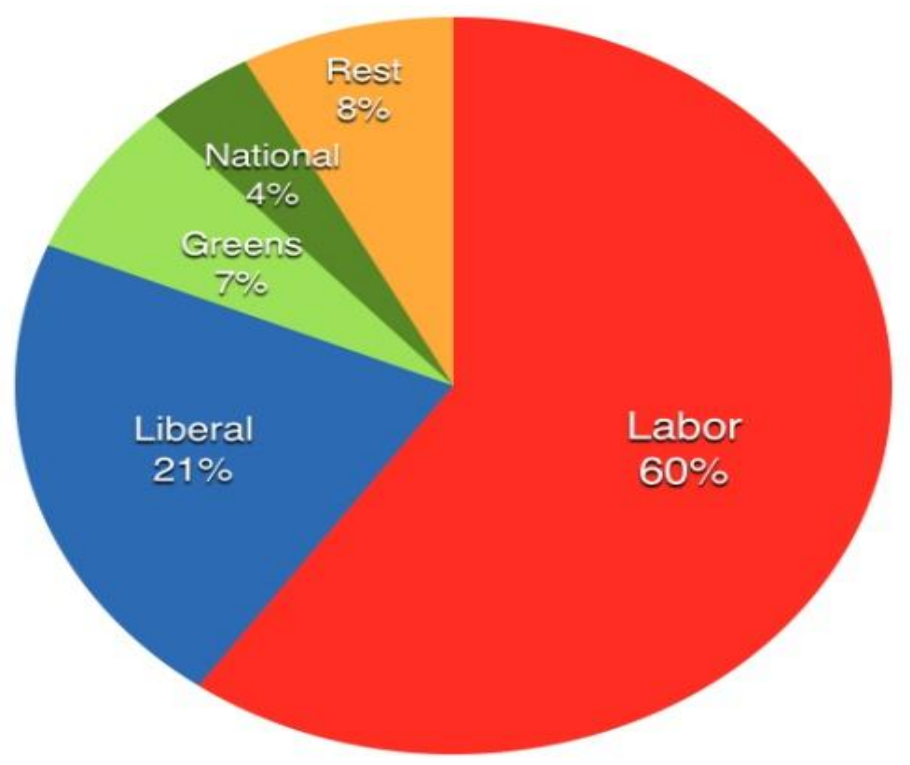


Figure 3: Seats Won by Parties in WA across 3 Elections, Showing the Rise of Labor and the Decline of Liberal and National Seats

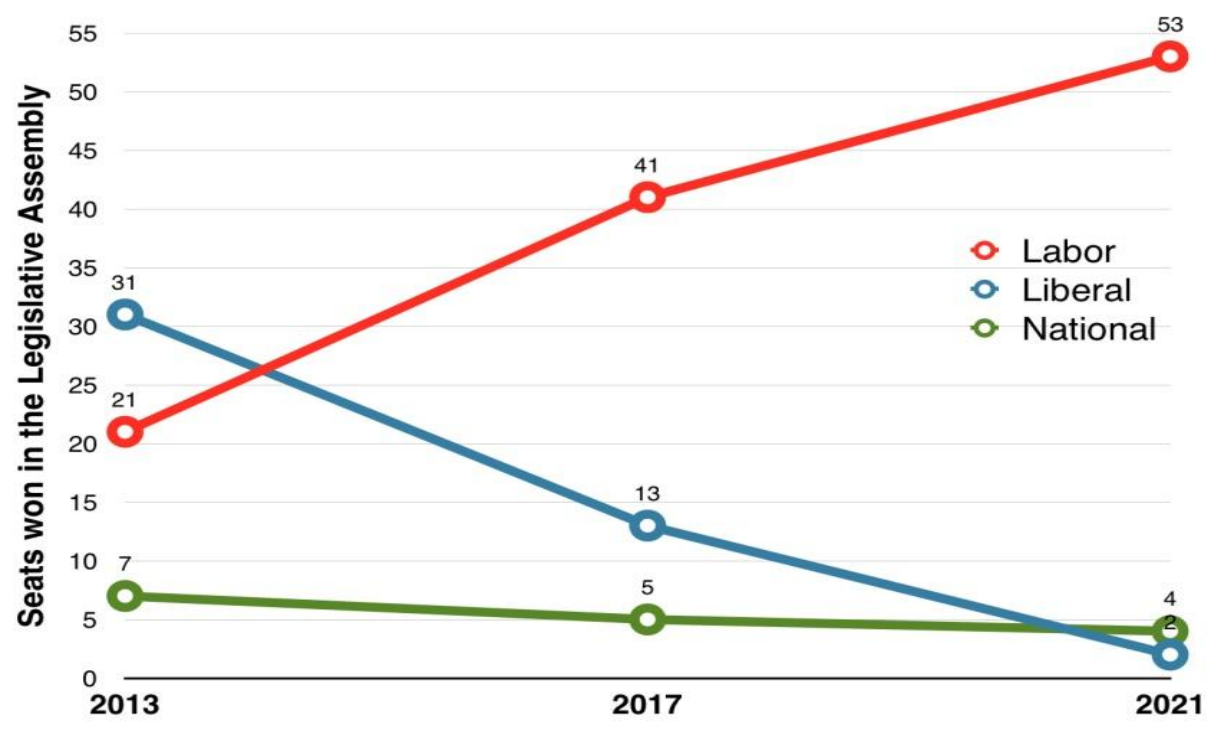

The sixth Covid pandemic election was held in Tasmania where the incumbent government was center-right (in contrast to the other five elections where center-left governments were incumbent). So, the Tasmania election was destined to break the pattern set by the previous 5 Covid elections - with either the incumbent government returned or a center-left party elected to govern. The incumbent won, going into the election with 13 (of the 25 seats) and coming out of the election with 13 seats (a minimum of 13 seats are required to form the government). The pattern of re-electing Antipodean, incumbent governments during the Covid-19 pandemic was continued. Unlike the other five elections which were called in a timely way, the Tasmanian election was brought forward by one year. The electorate was in a mood for rewarding the maintenance of a Covid-safe state but conflicted with also a mood for punishing what was perceived by many as cynical opportunism in sending voters to the ballot box a full year before an election was due but just weeks after the WA election delivered a landslide vote for the WA incumbent government. In any event, there was no landslide in Tasmania where the incumbent government did manage to maintain the status quo of a government with the slimmest of majorities despite underperforming in non-Covid matters including infrastructure and ethics (Killick, 2021; McCormack, 2021).

\section{Discussion and Conclusion}

The results reported are good news for incumbent governments which have handled the pandemic well and kept their populations safe. In the six cases reported in the present paper, incumbent governments appear to have been rewarded at the ballot box for their management of the pandemic. There is no pretense that Covid19 has been the sole contributing factor in these electoral wins, nevertheless, the pandemic has been the dominant news story and the dominant event impacting social, business and employment throughout the pandemic. In an analysis of the New Zealand election, The Guardian observed that: Prime Minister Jacinda "Ardern's deft handling of the Covid-19 outbreak and resolute belief in science and experts was credited with earning the trust of New Zealanders, who cast early votes in record numbers, giving her party more votes than at any other election in the past five decades" (Roy \& Graham-McLay, 2020). Bloomberg reported: "For so many voters it comes down to Ardern ... Her leadership during this crisis has led to what we're seeing, which is a landslide for Labor" (Brockett, 2020). In an analysis of the WA election, The Sydney Morning Herald stated that: "Labor's Mark McGowan has romped it in on the back of extraordinary popularity in the state mostly due to his tough stance on COVID-19 control" (Cross, Rimrod, Juanola, Hastie, \& de Kruijff, 2021). The former leader of the WA Liberals, Liza Harvey, who lost her seat in the election, stated that: "I think this is very much about the people wanting to reward the premier" for his handling of the pandemic (Hopkin, 2021). 
WA has been a safe haven throughout the pandemic (Table 1). There has been a total of 9 Covid deaths in WA (compared to 909 in Australia), with a total of 938 Covid cases in WA (cf. 29,296 in Australia), and a total of 941,359 Covid tests administered in WA (cf. 15,528,444 in Australia), with a WA rate of $0.1 \%$ testing positive (cf. $0.2 \%$ in Australia) (DoH, 2021). Premier McGowan achieved this success by a closed border policy along with other precautions. The WA border closure was maintained despite Australian Prime Minister Scott Morrison's urging against state border closures (Hondros, 2020). A Queensland-based mining magnate, Clive Palmer, sued the WA state along with the WA Premier in the High Court over WA border closures. The Australian Federal government ('Canberra') joined Clive Palmer in this action (Bell \& Hamlyn, 2020) before later withdrawing (Carmody, 2020). The actions were lost (Byrne, Shine, \& Al Jrood, 2020). Mark McGowan stood firm during this siege by the Corona virus, as well as by Clive Palmer and Scott Morrison, he kept the state safe, and this earned the respect of West Australians. Bullying by 'Canberra' is a sure-fire way to raise the hackles of West Australians, and this clumsy effort was no exception. At his victory speech, on the night of the election, Mark McGowan stated: "I also thank the people who voted Labor for the first time in their lives across Western Australia".

The remarkable election victory was enabled by this influx of fresh support. "Can I also acknowledge those Western Australians who didn't vote for us and I promise to work for everyone across Western Australia over these coming four years ... I promise we won't let Western Australia down" (9News, 2021). Two weeks before the election, the leader of the WA Liberals, Zac Kirkup, embarked on "the remarkable campaign tactic of admitting that the Liberal Party "cannot win the election" (Green, 2021, p.2). On election night, Kirkup described the result as a "gutting loss" for the Liberals (Hastie, 2021). Kirkuk lost his own seat with a 14.3\% swing against him (ABC News, 2021). The result was summed up: "What we are seeing is the worst election result for a party in state history in any state in Australia at any time" (Rimrod, 2021) The state-wide WA swing to Labor was 17.7\%. WA's Premier, Mark McGowan, declared on election night that: "our democracy should always be based on decency, civility, respect for one another and acknowledging each other" (West Australian, 2021). McGowan presents as a 'decent bloke' (in the Australian parlance) and he has presided over a trusted government without serious scandals or missteps over the past four years. In easing Covid restrictions, Mark McGowan frankly and honestly, acknowledged: "Hard work of Western Australians, which has enabled the virus to be controlled and ensured there is no community spread in WA" (McGowan, 2021).

The first five pandemic elections saw incumbent governments, all center-left governments, enjoying electoral wins as reported here (Table 2). In the light of the remarkable WA election result (Labor won 53 of 59 seats), the incumbent Liberal Tasmanian government opted to bring their election forward by a year (to 1 May 2021) (Langenberg, 2021). The Tasmanian Premier, Peter Gutwein, has undoubtedly earned the respect of Tasmanians for keeping the state safe (Table 1) with border closures and other Covid-safe measures (Baker, 2020). The self-serving early election gambit of the Tasmania Liberal government could have been expected to pay off, given that state government pandemic strategies have kept the state safe (Table 1) and given that the Labor opposition in Tasmania has widely been regarded as 'missing in action' during the more than 12 months of the pandemic, and despite that the Liberals have sought to reignite the forestry wars (Ajani, 2007), have favored secrecy over transparency (Baker, 2020), have disappointed the electorate with missed infrastructure opportunities (Killick, 2020), and generally have little to brag about other than keeping the state Covid-safe. As one commentator observed: "This generation will die waiting for the Libs to get the [recovery] plan shovel-ready.

They're notorious for failing to follow up on announcements with swift action" (Prismall, 2021). The Tasmanian electoral result, of returning the status quo (Table 2), reflected the unidimensional successful track record of the Tasmanian Liberals (center-right) of keeping Tasmania Covid-safe while failing to deliver on past promises and failing to take up visionary opportunities (such as light rail for Hobart northern suburbs, multi-port ferry service for the Derwent River, and a fast ferry service to the mainland using worldleading technical prowess pioneered, developed and proven by Tasmania's Incat shipbuilder). There is an upcoming federal election for Australia due in 2022. The Liberal incumbent government in Canberra, under Prime Minister Scott Morrison, has kept Australia Covid-safe during the pandemic (Table 1). However, Morrison has handled other issues, including, China relations (Hurst, 2021), bushfire responses (Feik, 2020), women's issues and misconduct scandals (Sackville, 2021), with noteworthy ineptitude. These multiple missteps by the Morrison government suggest that a federal election in Australia, is not imminent, despite the 
temptation to call an early election to take advantage of the currently prevailing dual opportunities of a Covid-safe effect and the enduring lame federal opposition presented by federal Labor (Stratton, 2021).

A reviewer asked, are there policy implications of these election results? Incumbents start with the advantage of incumbency. If they perform well they may be rewarded at the ballot box, even massively (e.g. WA). If they perform well on one dimension (Covid-safety), but otherwise fail to deliver on prior election promises (e.g. transparency in the declaration of political donations), and behave cynically by calling an election prematurely for their own self-interest, the reward may be seriously diluted (e.g. Tasmania). The Tasmania election result returned the status quo; pre and post-election, the chamber recorded: 13 Liberals, 9 Labor, 2 Greens, and 1 Independent. The Covid effect identified in this paper, favoring incumbents in Covid-safe jurisdictions may be diluted for future elections as Covid fades and local issues return to the fore. The elections reported in the present paper were held in the midst of the pandemic and within the context of overwhelming attention and relentless media reportage of the Covid-19 pandemic. As and when the currently ubiquitous Covid pandemic issues recede into the past, local issues can be expected to come once again into clear view, and incumbent governments can once again expect punishment at the ballot box for real or perceived incompetence, ineptitude, corruption, and scandal (and perhaps reward for the contrary).

At the time of writing, just when the Corona virus pandemic will recede into the past remains unclear, and, in the meantime, incumbent governments that have kept their constituents safe can expect to reap some electoral reward as a Covid effect for that safety. Six elections in six Covid-safe electorates returned six incumbents. Rather than policy implications, there are performance implications. Keep the population safe is an implicit and foundational policy position for the government even a government's foundational raison d'être. In Australia and New Zealand, the governments were 'feeling their way' through the pandemic, developing policy on the fly, and it was the performance outcomes rather than the policy positions that were rewarded at the ballot box. Islands bear an intrinsic biosecurity advantage of geography. Antipodean governments and their constituents have a long history of biosecurity awareness and this may account in some measure for the general compliance of the populations with Covid-safe government impositions and restrictions, and the success thereof. For incumbent governments that have failed their constituents during the Corona virus pandemic, the Covid-safe effect reported in the present paper may act in reverse with such governments, and lead to punishment at the ballot box - but that is another story, an opportunity for aspirational oppositions to reap their own Covid effect, and an opportunity for further research.

\section{References}

9 News. (2021). Breaking News: Premier Mark McGowan Addresses WA. Perth: Nine Network <nine.com.au> 14 March.

ABC News. (2021). Western Australia Election 2021 Results. Perth: ABC News <abc.net.au> 24 March.

Adams, J. (2014). Women and the Vote: A World History. Oxford: Oxford University Press.

AEC. (2019). Australian Electoral Commission Annual Report 2018-19. Canberra: Australian Electoral Commission (AEC).

Aiton, D. \& Lane, T. (2000). The First Century: Australia's Federal Elections since Federation. Melbourne: Information Australia.

Ajani, J. (2007). The Forest Wars. Melbourne: Melbourne University Press.

Baker, E. (2020). Peter Gutwein's pandemic response won praise, but has the shine gone off? ABC News, 31 October.

Barber, S. (2017). Federal election results 1901-2016. Parliamentary Library Research Paper Series, 201617(31 March), 1-150.

Bean, C. \& McAllister, I. (2015). Documenting the inevitable: Voting behavior at the 2013 Australian election. In C. Johnson \& J. Wanna (Eds.), Abbott's Gambit: The 2013 Australian Federal Election (pp. 411424). Canberra: ANU Press.

Bell, F. \& Hamlyn, C. (2020). Scott Morrison warns Clive Palmer 'highly likely' to win WA border battle. The New Daily, 29 July.

Brockett, M. (2020). Jacinda Ardern set for big election win as voters reward Covid success. Bloomberg, 15 October.

Byrne, E., Shine, R. \& Al Jrood, T. (2020). Clive Palmer loses High Court challenge to Western Australia's coronavirus border closure. ABC News, 6 November. 
Cameron, S. \& McAllister, I. (2019). The 2019 Australian Federal Election: Results from the Australian Election Study. Canberra: Australian National University.

Carmody, J. (2020). Commonwealth withdraws from Clive Palmer border case, Prime Minister's letter to WA Premier reveals. ABC News, 2 August.

Cross, D., Rimrod, F., Juanola, M. P., Hastie, H. \& de Kruijff, P. (2021). WA state election 2021 as it happened: Total Liberal wipeout as rockstar Premier Mark McGowan celebrates landslide win. Sydney: Sydney Morning Herald <smh.com.au> 14 March.

DoH. (2021). Coronavirus (COVID-19) current situation and case numbers. Canberra: Department of Health (DoH), Australian Government, 31 March.

Electoral Commission. (2020). New Zealand Election Results. Wellington, New Zealand: Electoral Commission.

Farrell, D. \& McAllister, I. (2006). The Australian Electoral System: Origins, Variations and Consequences. Sydney: UNSW Press.

Feik, N. (2020). A national disaster: On the PM's catastrophically inept response to Australia's unprecedented bushfires. The Monthly, 7 January.

Fowler, A. (2013). Electoral and policy consequences of voter turnout: Evidence from compulsory voting in Australia. Quarterly Journal of Political Science, 8, 159-182.

Ghebreyesus, T. A. (2020). WHO Director General's opening remarks at the media briefing on COVID-19, 11 March 2020. Geneva: World Health Organization.

Green, A. (2021). Election Preview. Perth: ABC News <abc.net.au> 4 March.

Hastie, H. (2021). A 'gutting loss' says Zac Kirkup. Sydney: Sydney Morning Herald <smh.com.au> 13 March.

Hondros, N. (2020). WA to go its own way on pandemic plan as rest of nation joins forces on borders. Sydney Morning Herald, 4 September.

Hopkin, M. (2021). Mark McGowan leads Labor landslide in WA as Liberals' worst fears are realized. The Guardian, 14 March.

Hurst, D. (2021). Press reset: can the Morrison government rebuild bridges with China - or is it too late? The Guardian, 23 January.

JCPML. (2006). Australian Governments 1939-1945. Perth: John Curtin Prime Ministerial Library (JCPML).

Killick, D. (2020). Opinion polling highlights continuing uncertainty about Bridgewater Bridge replacement. The Mercury, 8 May.

Killick, D. (2021). Liberals' infrastructure underspend labelled an 'absolute disgrace': The Liberal government promised to spend more than $\$ 1.1 \mathrm{bn}$ on infrastructure this year, but a new report has revealed only a fraction of that amount has been spent so far. Mercury, 15 May.

Langenberg, A. (2021). Peter Gutwein calls Tasmanian state election for May 1. ABC News, 26 March.

McCormack, M. (2021). False identities and firearms: Embattled MP Adam Brooks resigns amid accusations and charges. Mercury, 14 May.

McGowan, M. (2021). WA's strong progress enables further easing of restrictions. Perth: Press Release, Premier's Office, 5 March.

Prismall, B. (2021). White must offer hope, vision to voters and her party. The Examiner, 9 January.

Ramos, R. \& Sanz, C. (2019). Backing the incumbent in difficult times: The electoral impact of wildfires. Comparative Political Studies, 53(3-4).

Redmond, P. \& Regan, J. (2015). Incumbency advantage in a proportional electoral system: A regression discontinuity analysis of Irish elections. European Journal of Political Economy, 38(C), 244-256.

Rimrod, F. (2021). Uhlmann's damning appraisal. Sydney: Sydney Morning Herald <smh.com.au $>14$ March.

Roy, E. A. \& Graham-McLay, C. (2020). Jacinda Ardern to govern New Zealand for second term after historic victory. The Guardian, 18 October.

Sackville, K. (2021). Scott Morrison's speech after parliament sex acts proves he still doesn't get it. ABC News, 23 March.

Stratton, H. (2021). If Anthony Albanese steps down now, his replacement will be even worse. Catalyst, 30 January.

West Australian. (2021). State election 2021: Mark McGowan delivers victory speech after Labor's landslide win. The West Australian, 14 March.

Worldometer. (2021a). Coronavirus: New Zealand. USA: Worldometer < worldometers.info >, 31 March.

Worldometer. (2021b). Covid-19 Coronavirus Pandemic. USA: Worldometer <worldometers.info>, 31 March. 